\title{
Xanthohumol, a prenylated flavonoid from Hops, exerts anticancer effects against gastric cancer in vitro
}

\author{
SHANSHAN WEI ${ }^{1,2}$, TAOLI SUN ${ }^{3}$, JIE DU $^{4}$, BIKUI ZHANG ${ }^{1,2}$, DAXIONG XIANG ${ }^{1,2,5}$ and WENQUN LI ${ }^{1,2,5}$ \\ ${ }^{1}$ Department of Pharmacy, The Second Xiangya Hospital; ${ }^{2}$ Institute of Clinical Pharmacy, Central South University, Changsha, \\ Hunan 410011; ${ }^{3}$ Key Laboratory Breeding Base of Hu'nan Oriented Fundamental and Applied Research of \\ Innovative Pharmaceutics, College of Pharmacy, Changsha Medical University, Changsha, Hunan 410219; \\ ${ }^{4}$ Department of Pharmacy, Xiangya Hospital, Central South University, Changsha, Hunan 410078; \\ ${ }^{5}$ Hunan Provincial Engineering Research Center of Translational Medicine and Innovative Drug, \\ Changsha, Hunan 410011, P.R. China
}

Received May 4, 2018; Accepted September 13, 2018

DOI: $10.3892 / o r .2018 .6723$

\begin{abstract}
Xanthohumol (Xn), a prenylated flavonoid isolated from Hops (Humulus lupulus L.), has demonstrated potent anticancer activity in multiple types of cancer. However, the effect of $\mathrm{Xn}$ on gastric cancer (GC) remains unknown. The aim of the present study was to investigate the effect of Xn on GC cell proliferation, apoptosis and metastasis. It was observed that Xn decreased the viability of GC cells, with very low or no toxicity to normal gastric epithelial cells GES-1 at a concentration of 1-100 $\mu \mathrm{M}$. The proliferation of AGS cells was inhibited by $\mathrm{Xn}$, as indicated by the decreased number of EdU-positive cells. Xn treatment increased the number of apoptotic cells, downregulated the expression of Bcl-2 and upregulated the expression of Bax, suggesting induction of apoptosis. The results from the wound healing and Transwell assays indicated that Xn suppressed AGS cell metastasis. Moreover, Xn induced reactive oxygen species (ROS) overproduction and inhibited nuclear factor (NF)- $\kappa \mathrm{B}$ signaling in AGS cells, which was reversed by the ROS inhibitor $\mathrm{N}$-acetylcysteine (NAC). NAC suppressed the effect of Xn on the proliferation, apoptosis and metastasis of AGS cells. Taken together, these results suggest that Xn exerts anticancer effects against GC via induction of ROS production and subsequent
\end{abstract}

Correspondence to: Professor Daxiong Xiang or Dr Wenqun Li, Department of Pharmacy, The Second Xiangya Hospital, Central South University, 139 Renmin Road, Changsha, Hunan 410011, P.R. China

E-mail: xiangdaxiong@163.com

E-mail: liwq1204@csu.edu.cn.

Abbreviations: GC, gastric cancer; Xn, xanthohumol; NSCLC, non-small-cell lung cancer; DHE, dihydroethidium; ROS, reactive oxygen species; SOD, superoxide dismutase; NF- $\kappa \mathrm{B}$, nuclear factor $\kappa \mathrm{B}$

Key words: xanthohumol, gastric cancer, proliferation, apoptosis, metastasis inhibition of $\mathrm{NF}-\kappa \mathrm{B}$ signaling. Therefore, $\mathrm{Xn}$ may be a promising candidate treatment against GC progression.

\section{Introduction}

Gastric cancer (GC), the fourth most commonly diagnosed malignant disease following lung, breast and colorectal cancer, is the second leading cause of cancer-related mortality worldwide. The National Comprehensive Cancer Network (NCCN) guidelines recommend surgery, chemotherapy and radiation therapy for GC patients (1). However, despite the fact that the incidence of gastric cancer has decreased worldwide over the last 3 decades, its burden remains substantial due to common relapses originating from a residual nidus (2). Therefore, there is an urgent need to identify novel anticancer agents with milder toxicity profiles to enhance the efficacy of GC treatments.

Accumulating evidence suggests that natural, bioactive substances from plants (phytochemicals) may be promising chemopreventive and chemotherapeutic agents in the treatment of several human cancers. A number of phytochemicals have been found to exert anticancer effects in in vitro studies, some of which have been confirmed in vivo, such as certain polyphenols (e.g., resveratrol and gallocatechins) and flavonoids (e.g., methoxy licoflavanone and alpinumisoflavone), among others (3). More importantly, clinical trial evaluations of several phytochemicals have been conducted in cancer patients. For example, the anticancer activity of resveratrol was evaluated in patients with colorectal cancer and hepatic metastases in a phase I randomized double-blind pilot study, which reported that resveratrol significantly increased the apoptosis of hepatic cancer cells (4). Xanthohumol [Xn; 3'-(3,3-dimethylallyl)-2',4',4-trihydroxy-6'-methoxychalcone], the most abundant prenylated flavonoid (0.1-1\% of dry weight) in Hops (Humulus lupulus L.), may be isolated from the female inflorescences, as shown in Fig. 1. Xn is also a constituent of beer, a major dietary source of prenylated flavonoids, where it has been found at concentrations of up to $0.96 \mathrm{mg} / \mathrm{l}$ $(1.95 \mu \mathrm{M})(5)$. In recent years, an increasing number of studies demonstrated the broad-spectrum anticancer activity of $\mathrm{Xn}$ in 
NSCLC (6), hepatocellular carcinoma (7), breast cancer (8), leukemia (9), prostate cancer (10) and glioblastoma (11). Exposure of cancer cells to Xn may inhibit their proliferation, migration and invasion, as well as induce apoptosis and cell cycle arrest. However, to the best of our knowledge, the effects of $\mathrm{Xn}$ on GC have not been investigated to date.

The present study aimed to investigate the anticancer activity of Xn against GC cells in vitro, and preliminarily explore the underlying mechanism. The effects of $\mathrm{Xn}$ on the proliferation, apoptosis, migration and invasiveness of GC cells were evaluated; in addition, whether these effects involved reactive oxygen species (ROS) production and nuclear factor $(\mathrm{NF})-\kappa \mathrm{B}$ signaling was further investigated.

\section{Materials and methods}

Cell culture. GC cells (AGS, SGC-7901 and MGC-803) and normal gastric epithelial cells GES-1 were obtained from the American Type Culture Collection (Rockville, MD, USA). These cell lines were cultured in RPMI-1640 (HyClone, Logan, UT, USA), supplemented with $10 \%$ heat-inactivated fetal bovine serum (FBS; Gibco-Invitrogen; Thermo Fisher Scientific, Inc., Carlsbad, CA, USA) in a humidified atmosphere with $5 \% \mathrm{CO}_{2}$ at $37^{\circ} \mathrm{C}$.

Reagents. Xn was obtained from Sigma-Aldrich; Merck KGaA (St. Louis, MO, USA). CellTiter $96^{\circledR}$ AQueous One Solution Cell Proliferation Assay kit was purchased from Promega Corporation (Madison, WI, USA). The 5-ethynyl-20-deoxyuridine (EdU) incorporation assay kit was purchased from RiboBio (Guangzhou China), the FITC Annexin V Apoptosis Detection Kit I was obtained from BD Pharmingen (BD Biosciences, Franklin Lakes, NJ, USA). Antibodies against Bcl-2 (rabbit polyclonal antibody, dilution 1:1,000; cat. no. ab194583), Bax (rabbit monoclonal antibody, dilution 1:1,000; cat. no. ab32503), p-IкB $\alpha$ (rabbit monoclonal antibody, dilution 1:1,000; cat. no. ab133462), IкB $\alpha$ (rabbit monoclonal antibody, dilution 1:1,000; cat. no. ab32518), p65 (rabbit polyclonal antibody, dilution 1:1,000; cat. no. ab16502), histone H3 (rabbit polyclonal antibody, dilution 1:1,000; cat. no. ab1791) and GAPDH (rabbit polyclonal antibody, dilution 1:1,000; cat. no. ab9485) were obtained from Abcam (Cambridge, UK). ROS and superoxide dismutase (SOD) assay kits were purchased from Beyotime Institute of Biotechnology, Ltd. (Shanghai, China).

Cell viability assay. Cell proliferation was measured by the CellTiter $96^{\circledR}$ AQueous One Solution Cell Proliferation Assay kit, as reported previously (12). After treatment with Xn for $24 \mathrm{~h}$, the cells were incubated with $20 \mu \mathrm{l} /$ well MTS solution for $1 \mathrm{~h}$, and then measured using an optical density reader at $570 \mathrm{~nm}$ (BioTek, Winooski, VT, USA).

EdU incorporation assay. A total of $100 \mu \mathrm{l}$ of $50 \mu \mathrm{M}$ EdU diluent medium was added into each well for $3 \mathrm{~h}$. The cells were fixed using $4 \%$ paraformaldehyde and incubated with $2 \mathrm{mg} / \mathrm{ml}$ aminoacetic acid for $5 \mathrm{~min}$ with oscillation. The cells were then incubated with $100 \mu 10.5 \%$ Triton X-100 added into each well with 10 min of oscillation followed by $100 \mu \mathrm{l}$ of $1 \mathrm{X}$ Apollo ${ }^{\circledR} 488$ fluorescent staining reaction liquid for $30 \mathrm{~min}$ at $37^{\circ} \mathrm{C}$. DAPI was used to stain the cell nuclei. The EdU incorporation rate was expressed as the ratio of EdU-positive cells (green cells) to total DAPI-positive cells (blue cells).

Flow cytometric analysis. Flow cytometric analysis was performed according to the manufacturers' instructions (BD Biosciences). Cells were washed twice with cold phosphate-buffered saline (PBS) and then resuspended in $1 \mathrm{X}$ binding buffer at a concentration of $1 \times 10^{6}$ cells $/ \mathrm{ml}$. A total of $100 \mu \mathrm{l}$ of the solution $\left(1 \times 10^{5}\right.$ cells) was transferred to a $5-\mathrm{ml}$ culture tube. After adding $5 \mu \mathrm{l}$ FITC Annexin V and $5 \mu \mathrm{l}$ propidium iodide (PI), the cells were gently vortexed and incubated for $15 \mathrm{~min}$ at room temperature $\left(25^{\circ} \mathrm{C}\right)$ in the dark, followed by the addition of $400 \mu \mathrm{l}$ of $1 \mathrm{X}$ binding buffer to each tube. Analysis by flow cytometry was performed within $1 \mathrm{~h}$.

Western blotting. Proteins were extracted with RIPA buffer (containing $0.1 \%$ PMSF), separated by $10 \%$ SDS/PAGE and transferred to polyvinylidene fluoride membranes. The membranes were then incubated with primary antibodies overnight at $4^{\circ} \mathrm{C}$, and horseradish peroxidase-conjugated goat anti-mouse or goat anti-rabbit secondary antibody (sc-2005, 1:2,000 and sc-2030, 1:5,000; Santa Cruz Biotechnology, Inc., Santa Cruz, CA, USA) for $1 \mathrm{~h}$. The chemiluminescence signals were detected with the EasySee Western Blot Kit (Beijing TransGen Biotech, Beijing, China). ImageJ 1.43 software (National Institutes of Health, Bethesda, MD, USA) was used for densitometric analysis.

Wound healing assay. A p200 pipette tip was used to create a scratch after the cells had grown to $80-90 \%$ confluence in 6-well culture plates. Images were captured at 0,24 and $48 \mathrm{~h}$ after wounding. To ensure that all wounds were of the same width at the beginning of each experiment, an ocular ruler was used to measure wound width.

Transwell assay. Transwell inserts (24-well) with an 8- $\mu \mathrm{m}$ pore size (Corning Incorporated, Corning, NY, USA) were used in the migration and invasion assays. The invasion assay was performed by precoating the Transwell inserts with Matrigel Basement Membrane Matrix (BD Biosciences). Briefly, the protocol was as follows: Cells suspended in serum-free medium with different concentrations of Xn were seeded in the upper chamber and were allowed to transmigrate towards the bottom chamber, which contained medium with $15 \%$ FBS for $24 \mathrm{~h}$. The membrane inserts were then fixed with $4 \%$ paraformaldehyde and stained with $1 \%$ gentian violet solution. Images were captured from each membrane, and the number of migrating and invading cells was counted under a microscope.

Intracellular ROS and SOD activity measurement. The fluorescent probe dihydroethidium (DHE) was used to monitor intracellular ROS levels. Intracellular DHE is oxidized to ethidium, which binds to DNA and stains the nuclei bright fluorescent red. Cells were incubated with different concentrations of Xn and $5 \mathrm{mM}$ DHE for 0,1 and $3 \mathrm{~h}$. The cultures were washed twice with ice-cold PBS, then visualized using a Zeiss inverted fluorescence microscope (Carl Zeiss AG, Oberkochen, Germany). The total red fluorescence intensities of 5 views per 


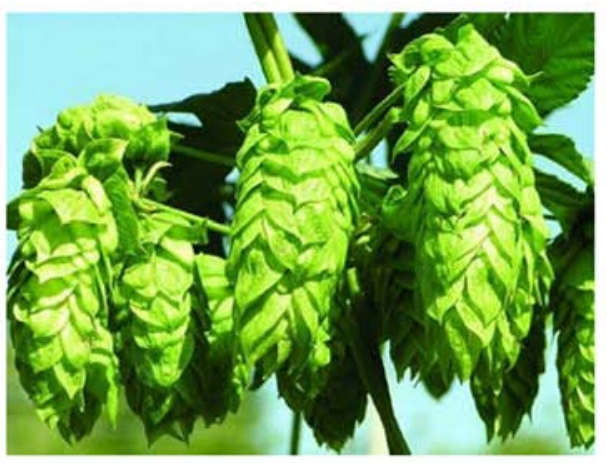<smiles>COc1cc(O)c(CC=C(C)C)c(O)c1C(=O)/C=C/c1ccc(O)cc1</smiles>

Figure 1. Hops (Humulus lupulus L.) and structure of xanthohumol.

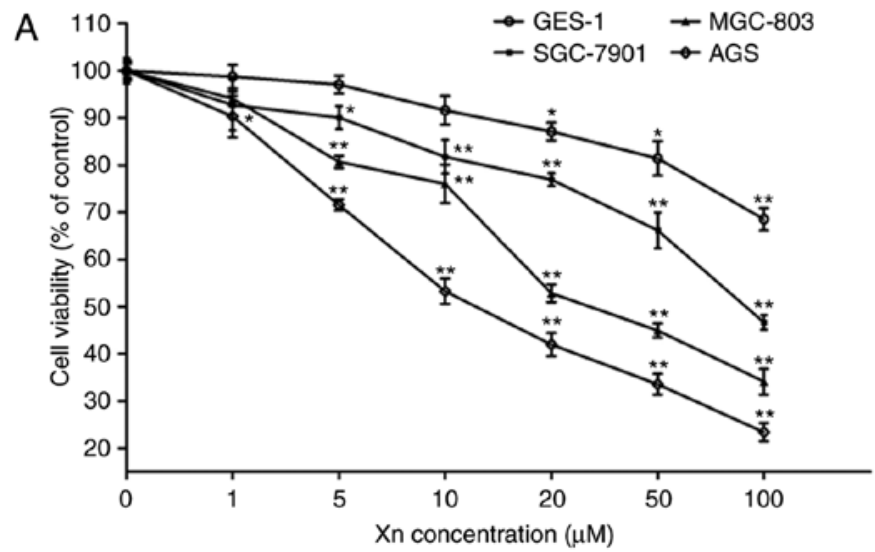

$\mathrm{B}$

\begin{tabular}{cc}
\hline Cell type & $\mathrm{IC}_{50}(\mu \mathrm{M})$ \\
\hline GES-1 & 285.26 \\
SGC-7901 & 111.16 \\
MGC-803 & 35.81 \\
AGS & 16.04 \\
\hline
\end{tabular}

Figure 2. Cytotoxicity of xanthohumol (Xn) on GC cells and normal gastric epithelial cells. (A) GC cells (MGC-803, SGC-7901 and AGS) and normal gastric epithelial cells (GES-1) were treated with Xn at concentrations of 0-100 $\mu \mathrm{M}$ for $24 \mathrm{~h}$. (B) The $\mathrm{IC}_{50}$ for each cancer cell line was calculated according to the data in (A). Cell viability was determined by the MTS assay. Treatment with $0 \mu \mathrm{M}$ Xn was used as control. Data are expressed as mean \pm standard error of the mean. $\mathrm{n}=3 .{ }^{*} \mathrm{P}<0.05,{ }^{* *} \mathrm{P}<0.01$ vs. control $(0 \mu \mathrm{M} \mathrm{Xn})$.

well were quantitated using ImageJ analysis software (National Institutes of Health). Total SOD activity was determined by detecting superoxide radicals generated from hypoxanthine and xanthine oxidase, according to the manufacturer's instructions (Beyotime Institute of Biotechnology, Ltd.).

Statistical analysis. The results are presented as means \pm standard error of the mean. Statistical analysis was performed by analysis of variance followed by the Newman-Student-Keuls test for multiple comparisons. The results were considered statistically significant when $\mathrm{P}<0.05$.

\section{Results}

Cytotoxicity of Xn on GC cells and normal gastric epithelial cells. To investigate the effect of Xn on GC, the cytotoxicity of Xn on GC cell lines (AGS, SGC-7901 and MGC-803) was determined by the MTS assay after $24 \mathrm{~h}$. As shown in Fig. 2, Xn significantly inhibited the viability of AGS, SGC-7901 and MGC-803 cells in a dose-dependent manner, with an $\mathrm{IC}_{50}$ of 16.04, 35.81 and $111.16 \mu \mathrm{M}$, respectively. The highest inhibitory activity of Xn was observed in AGS cells. Thus, AGS cells and three concentrations distributed around its $\mathrm{IC}_{50}$ value $(5,10$ and $20 \mu \mathrm{M})$ were selected for further experiments.

To investigate whether the inhibition of $\mathrm{Xn}$ was selective for cancer cells, the effect of $\mathrm{Xn}$ on normal gastric epithelial cells (GES-1) was also tested. The results demonstrated that $\mathrm{Xn}$ exerted very mild or no toxic effects on GES-1 cells compared with GC cells, with an $\mathrm{IC}_{50}$ of up to $285.26 \mu \mathrm{M}$ (Fig. 2A and B). There was no cytotoxicity at concentrations of 0-10 $\mu \mathrm{M}$. Moreover, Xn exerted no effect on the proliferation or apoptosis of GES-1 cells (Fig. 3A-D), as indicated by the unchanged percentage of EdU-positive cells and the expression of apoptosis-related proteins (Bcl-2 and Bax) following treatment with $\mathrm{Xn}$. These results indicated that Xn selectively targets GC cells, but not normal cells.

Effect of Xn on the proliferation and apoptosis of AGS cells. In view of the abnormal proliferation of cancer cells playing a key role in the development and progression of GC (13), the effect of $\mathrm{Xn}$ on the proliferation of AGS cells was investigated through EdU assay. Following treatment with different concentrations of $\mathrm{Xn}$ for $24 \mathrm{~h}$, both the total number of cells and the percentage of EdU-positive cells were dose-dependently decreased (Fig. 4A and B), suggesting that Xn effectively suppresses the proliferation of AGS cells.

The decreased total number of cells under Xn treatment may be due to apoptosis induction in addition to proliferation inhibition. Therefore, the effect of Xn on the apoptosis of AGS cells was assessed by flow cytometry and the expression of apoptosis-related proteins. The results of flow cytometry demonstrated that $\mathrm{Xn}$ increased the percentage of apoptotic 
A
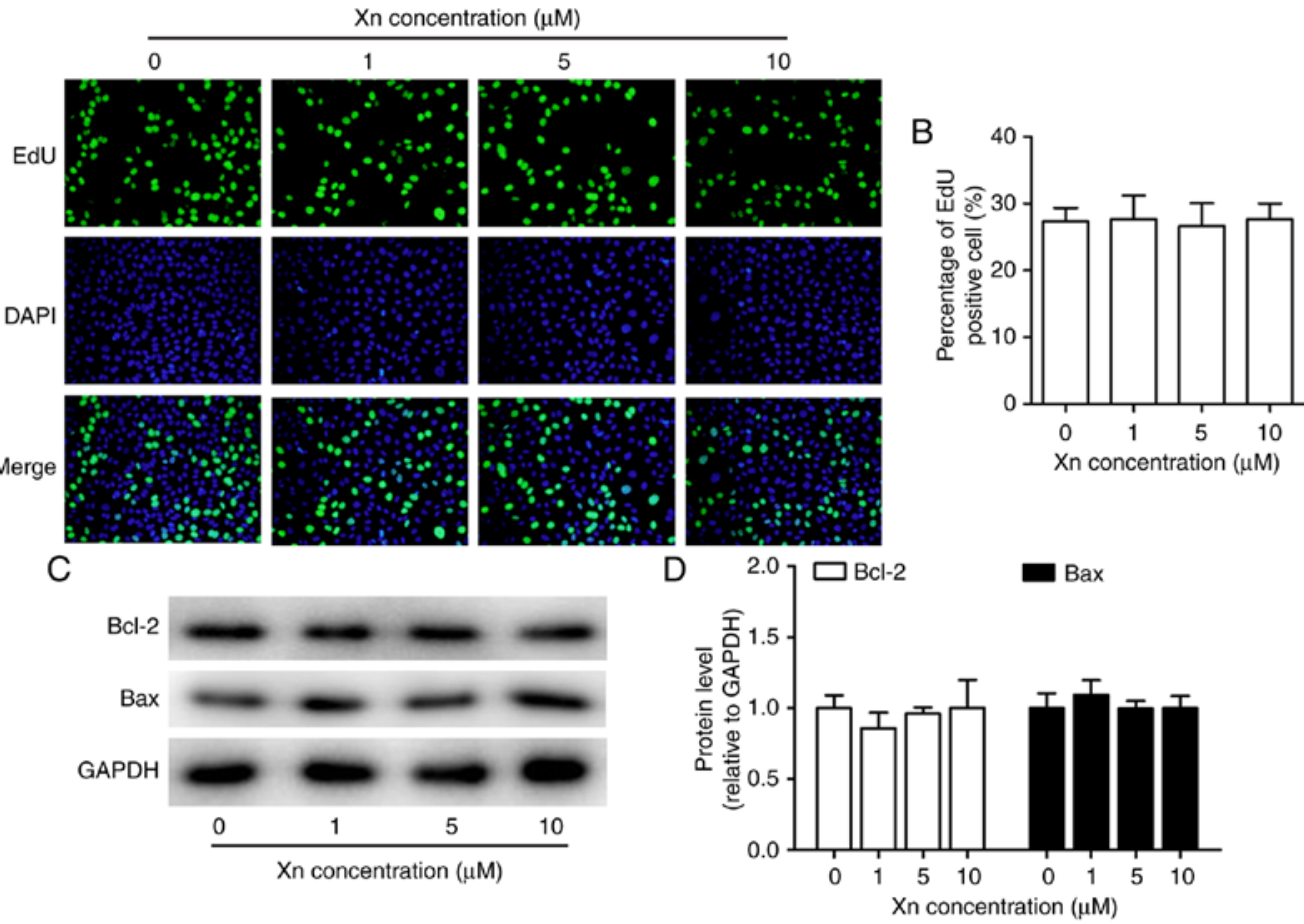

Figure 3. Effect of xanthohumol (Xn) on the proliferation and apoptosis of GES-1 cells. Cells were treated with different concentrations of Xn (0-10 $\mu \mathrm{M})$ for $24 \mathrm{~h}$. After treatment, (A) EdU incorporation assay was used to assess the proliferative ability; representative images are shown. (B) Percentage of EdU-positive cells. (C and D) The expression of apoptosis-related proteins, including pro-apoptosis protein Bax and anti-apoptosis protein Bcl-2, was measured through western blotting. Data are expressed as mean \pm standard error of the mean. $n=3$.

A
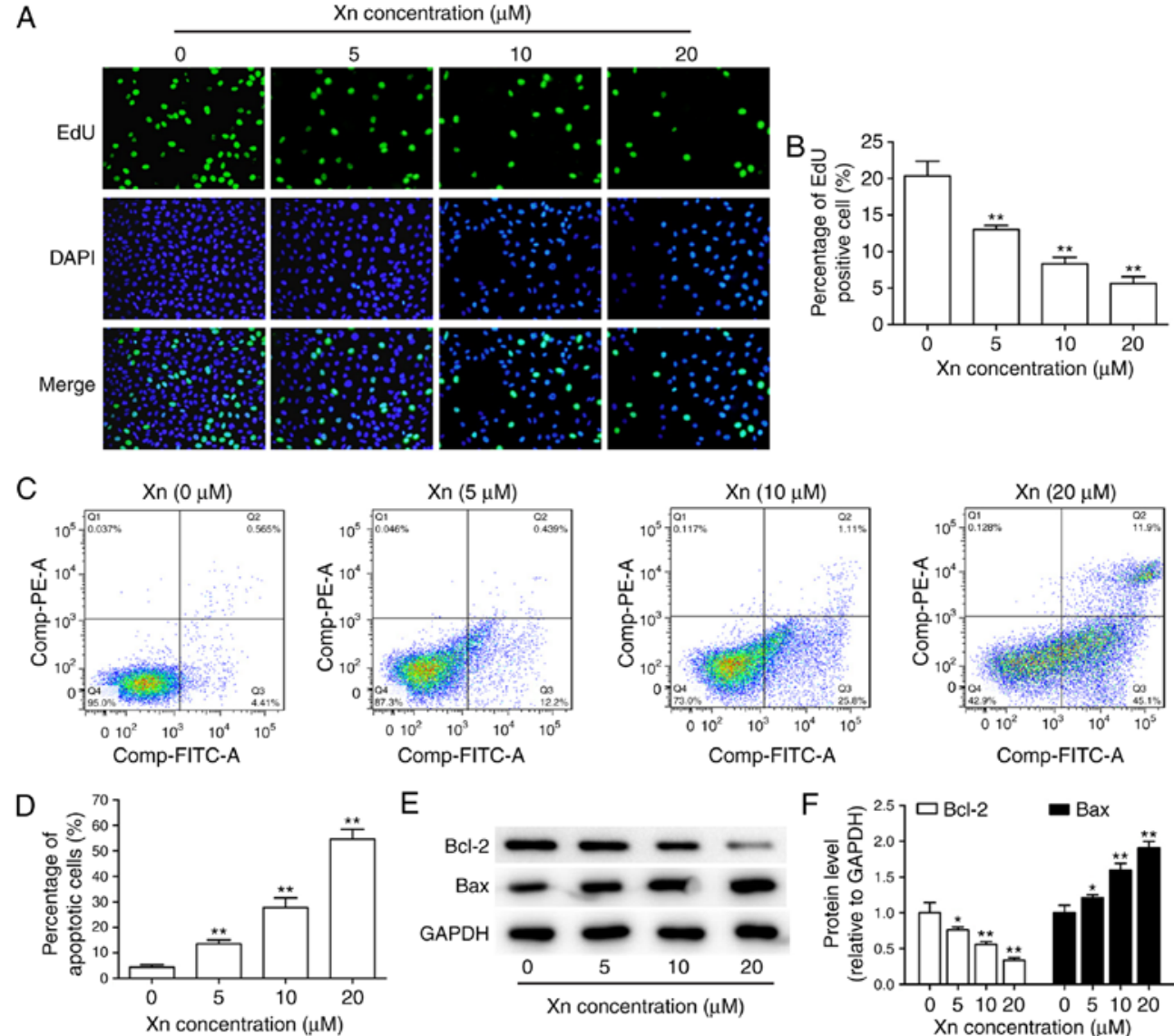

E
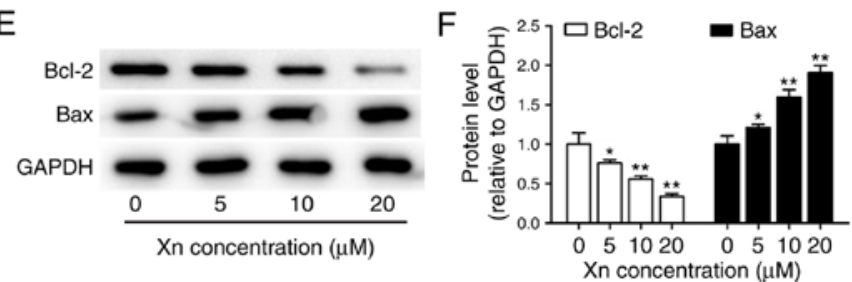

Figure 4. Effect of xanthohumol (Xn) on the proliferation and apoptosis of AGS cells. Cells were treated with different concentrations of Xn $(0-20 \mu \mathrm{M})$ for $24 \mathrm{~h}$. After treatment, (A) EdU incorporation assay was used to assess cell proliferative ability; representative images are shown. (B) Percentage of EdU-positive cells. (C and D) The number of apoptotic cells was determined by flow cytometry. (E and F) The expression of apoptosis-related proteins, including pro-apoptotic protein Bax and anti-apoptotic protein Bcl-2, was measured through western blotting. Data are expressed as mean \pm standard error of the mean. $\mathrm{n}=3 .{ }^{*} \mathrm{P}<0.05,{ }^{* *} \mathrm{P}<0.01$ vs. control $(0 \mu \mathrm{M} \mathrm{Xn})$. 
A

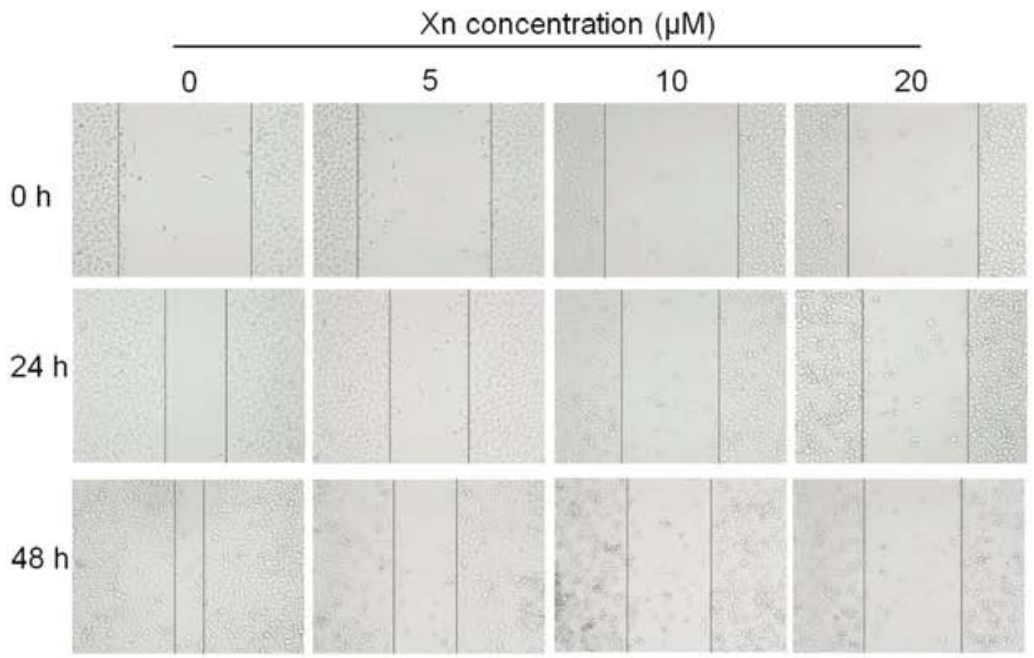

C

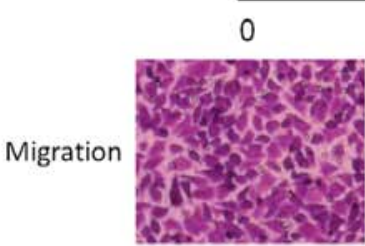

Invasion

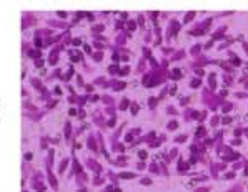

Xn concentration $(\mu \mathrm{M})$

5
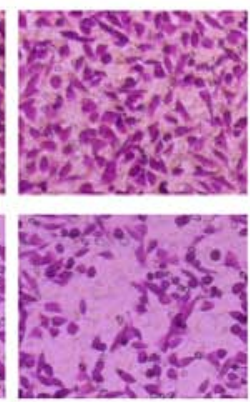

10

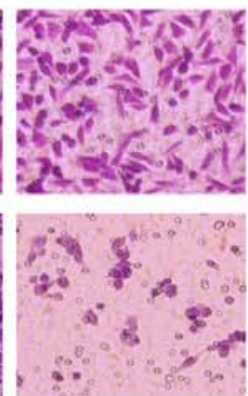

20

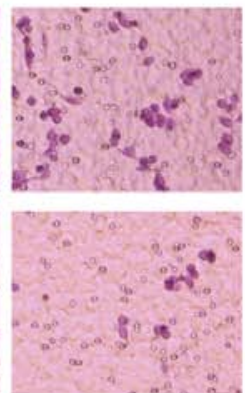

B

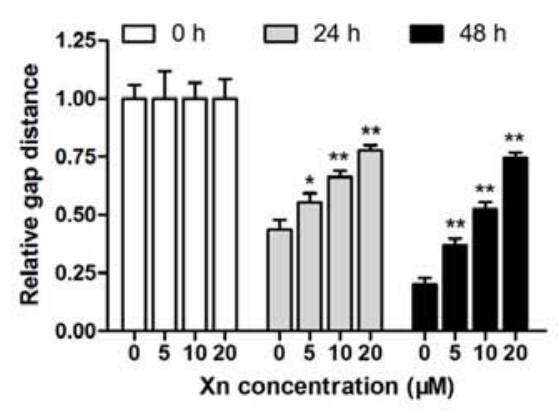

D

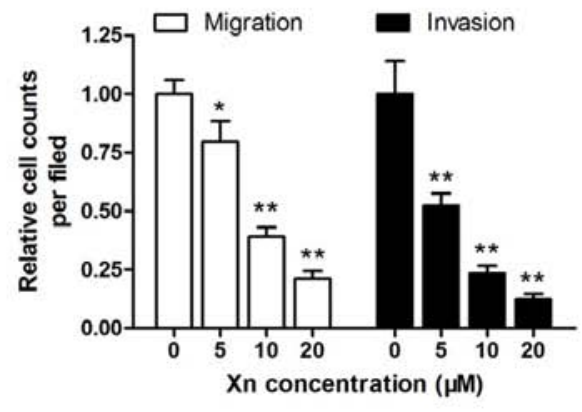

Figure 5. Effect of xanthohumol (Xn) on wound healing, migration and invasion of AGS cells. (A and B) Cells were treated with different concentrations of Xn $(0-20 \mu \mathrm{M})$ for 0,24 and $48 \mathrm{~h}$, followed by measurement of the relative wound width. (C and D) The Transwell assay was performed to evaluate cell migration and invasion ability; cells were treated with $\mathrm{Xn}$ as mentioned above in culture wells for $24 \mathrm{~h}$, and the migrating and invading cells were stained by crystal violet solution. Data are expressed as mean \pm standard error of the mean. $\mathrm{n}=3$. ${ }^{*} \mathrm{P}<0.05,{ }^{* *} \mathrm{P}<0.01$ vs. control $(0 \mu \mathrm{M} \mathrm{Xn})$.

cells in a dose-dependent manner. Early apoptosis was observed at concentrations of 5 and $10 \mu \mathrm{M}$, while incubation with $20 \mu \mathrm{M}$ $\mathrm{Xn}$ induced late apoptosis of AGS cells (Fig. 4C and D). Moreover, the expression of apoptosis-related proteins, including the pro-apoptotic protein Bax and the anti-apoptotic protein Bcl-2, may reflect the apoptosis level. As shown in Fig. 4E and F, Bcl-2 expression was decreased, while Bax expression was increased following treatment with $\mathrm{Xn}$ for $24 \mathrm{~h}$. Taken together, these results indicate that $\mathrm{Xn}$ induces the apoptosis of AGS cells.

Effect of Xn on the migration and invasion of AGS cells. Unrestricted metastasis is an important trait of GC, apart from disruptions in proliferation and apoptosis (14). The wound healing and Transwell assays were performed to determine the effect of $\mathrm{Xn}$ on cell motility. As shown in Fig. 5A and B, wound recovery was significantly delayed by $\mathrm{Xn}$ in a time- and dose-dependent manner; the inhibitory effect increased gradually with increasing incubation time and Xn concentration. In the Transwell assay, the migrating and invading cells were counted and normalized to mock. Xn treatment for $24 \mathrm{~h}$ significantly decreased the number of migrating and invading cells in a dose-dependent manner (Fig. 5C and D).
Effect of Xn on ROS production and SOD activity in AGS cells. Alterations of the intracellular redox balance are known to play a regulatory role in cell proliferation and apoptosis (15). To explore whether the proliferation inhibition and apoptosis induction by $\mathrm{Xn}$ involves ROS production, DHE was used to monitor the intracellular ROS levels derived from superoxide anion and superoxide. The representative fluorescent images and corresponding statistics (Fig. 6A and B) revealed that treatment with different concentrations of $\mathrm{Xn}$ for various times $(0,1$ and $3 \mathrm{~h})$ increased DHE fluorescence intensity in a time- and dose-dependent manner, suggesting that Xn induces ROS overproduction in AGS cells. It is well-known that SOD activity reflects the endogenous antioxidant ability against superoxide radicals. As shown in Fig. 6C, the relative SOD activity in AGS cells was decreased following exposure to $\mathrm{Xn}$ for $3 \mathrm{~h}$. These results indicated that $\mathrm{Xn}$ promotes ROS production and suppresses SOD activity, resulting in intracellular redox imbalance.

Effect of ROS inhibitor N-acetylcysteine (NAC) on the anticancer activity of Xn against GC. On the basis of abovementioned findings, to further determine whether ROS mediated the anticancer activity of Xn against GC, AGS cells were pre-treated with the ROS inhibitor NAC ( $5 \mathrm{mM})$ prior to 
A

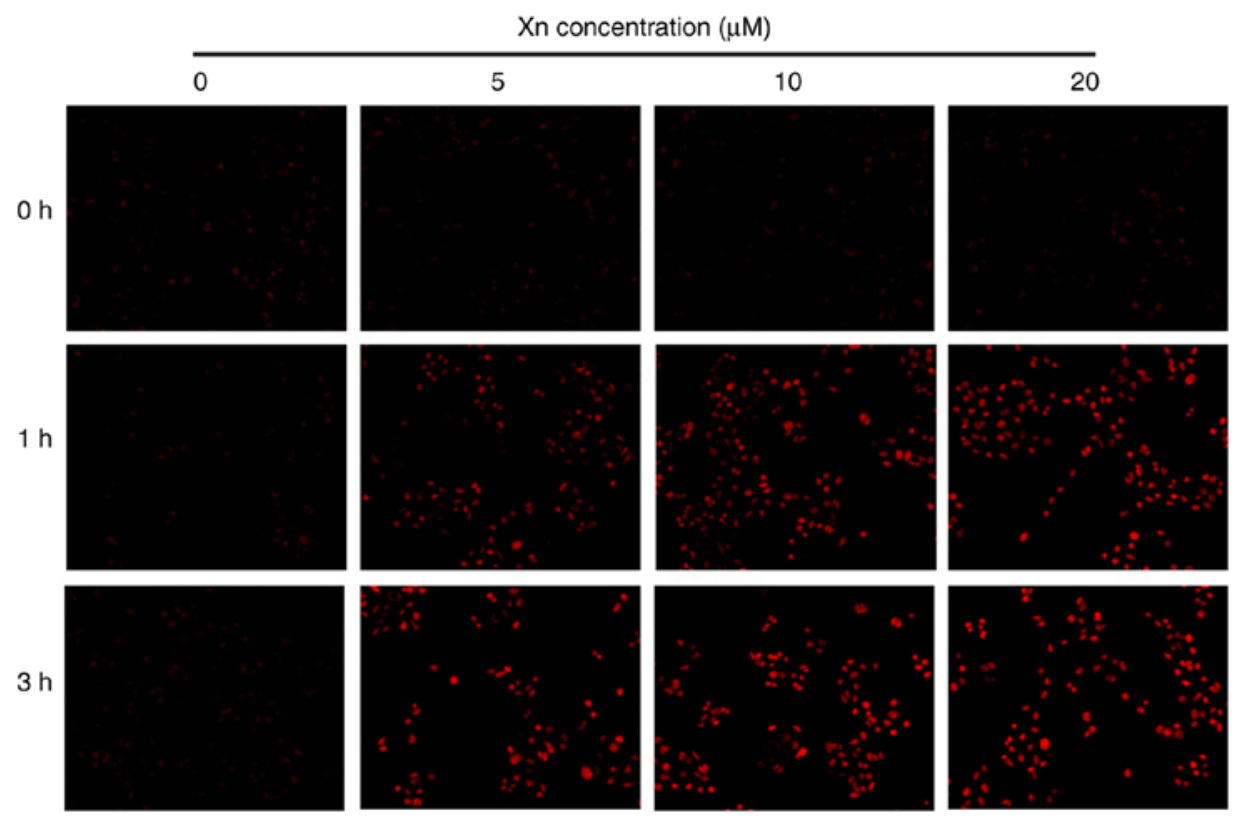

B

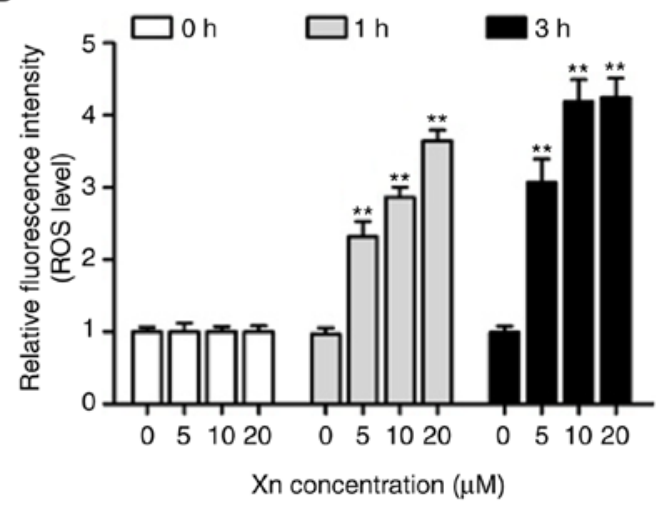

C

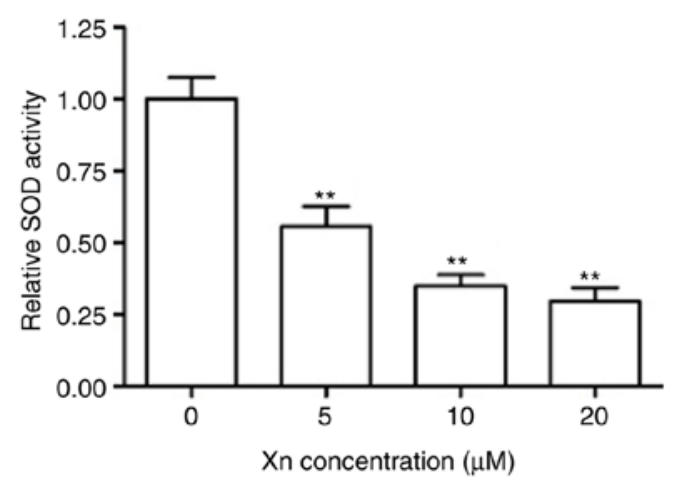

Figure 6. Effect of xanthohumol (Xn) on reactive oxygen species (ROS) production and superoxide dismutase (SOD) activity in AGS cells. (A and B) Cells were treated with different concentrations of Xn (0-20 $\mu \mathrm{M})$ for 0,1 and $3 \mathrm{~h}$, followed by measurement of ROS levels. Representative fluorescence images were captured, and red fluorescence intensity reflected the ROS level. (C) SOD activity was determined after the cells were treated with Xn as mentioned above for $3 \mathrm{~h}$. Data are expressed as mean \pm standard error of the mean. $\mathrm{n}=3$. ${ }^{* *} \mathrm{P}<0.01$ vs. control $(0 \mu \mathrm{M} \mathrm{Xn})$.

treatment with Xn $(20 \mu \mathrm{M})$. As shown in Fig. 7A and B, NAC inhibited the ROS overproduction induced by Xn $(20 \mu \mathrm{M})$. Furthermore, Xn decreased the percentage of EdU-positive cells, delayed wound recovery and induced cell apoptosis, as evidence by decreased Bcl-2 and increased Bax expression. However, these effects of $\mathrm{Xn}$ were reversed by pretreatment with NAC (Fig. 7C-H), indicating the inhibitory effect of the ROS inhibitor NAC on the anticancer activity of Xn.

Effect of Xn on the $N F-\kappa B$ signaling pathway in $A G S$ cells. NF- $\mathrm{NB}$ is known to modulate apoptosis, acting as a 'pro-survival' factor (16). NF- $\kappa \mathrm{B}$ signaling is responsible for regulating transcription through $\mathrm{NF}-\kappa \mathrm{B}$ p65 translocation into the nucleus, which is controlled by the targeted phosphorylation and subsequent degradation of $I \kappa B \alpha$. To examine the effect of Xn on NF- $\kappa \mathrm{B}$ signaling, the expression of $\mathrm{p}-\mathrm{I} \kappa \mathrm{B} \alpha$, $\mathrm{I} \kappa \mathrm{B} \alpha, \mathrm{p} 65$ (nuclear) and p65 (cytosolic) were measured upon $\mathrm{Xn}$ treatment for $24 \mathrm{~h}$. As shown in Fig. 8A-C, Xn decreased the expression of $\mathrm{p}-\mathrm{I} \kappa \mathrm{B} \alpha$ and increased the expression of $\mathrm{I} \kappa \mathrm{B} \alpha$, suggesting that the phosphorylation and subsequent degradation of $\mathrm{I} \kappa \mathrm{B} \alpha$ was inhibited by $\mathrm{Xn}$. Moreover, the expression of nuclear p65 was decreased, while the expression of cytosolic p65 was increased with Xn treatment (Fig. 8D-F), suggesting a suppressive effect of $\mathrm{Xn}$ on the NF- $\mathrm{B}$ p65 nuclear translocation. These results indicate that $\mathrm{Xn}$ inhibits $\mathrm{NF}-\kappa \mathrm{B}$ signaling.

Effect of the ROS inhibitor NAC on the $N F-\kappa B$ signaling pathway in Xn-treated AGS cells. High ROS levels have been shown to inhibit $\mathrm{NF}-\kappa \mathrm{B}$ activation, which in turn regulates cancer cell survival (16). To determine whether ROS mediated the anticancer activity of $\mathrm{Xn}$ through regulating $\mathrm{NF}-\kappa \mathrm{B}$ activation, the expression of $\mathrm{NF}-\kappa \mathrm{B}$ activation-related proteins was measured following pre-treatment with the ROS inhibitor NAC in Xn-treated AGS cells. The results demonstrated that $\mathrm{Xn}$ decreased the phosphorylation and subsequent degradation of $\mathrm{I} \kappa \mathrm{B} \alpha$, and suppressed the nuclear translocation of $\mathrm{NF}-\kappa \mathrm{B}$ p65, which were inhibited by NAC (Fig. 9A-F). Collectively, these results suggest that ROS mediates the anticancer activity of $\mathrm{Xn}$ against GC via the $\mathrm{NF}-\kappa \mathrm{B}$ signaling pathway. 
A
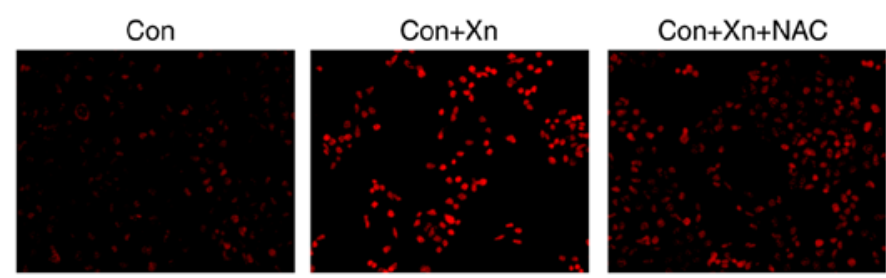

C
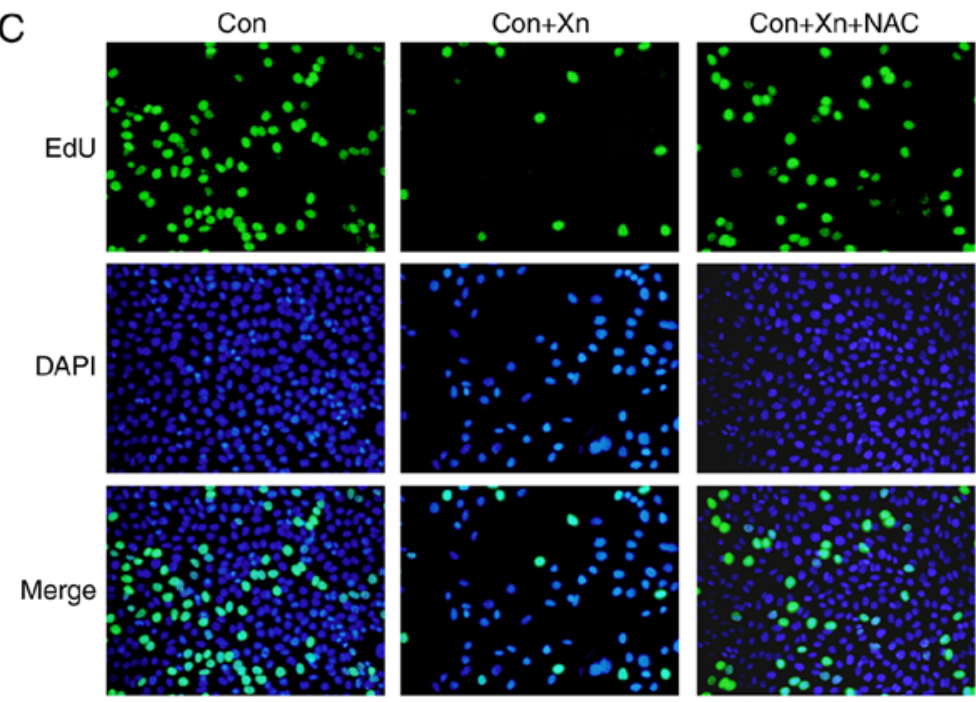

$E$
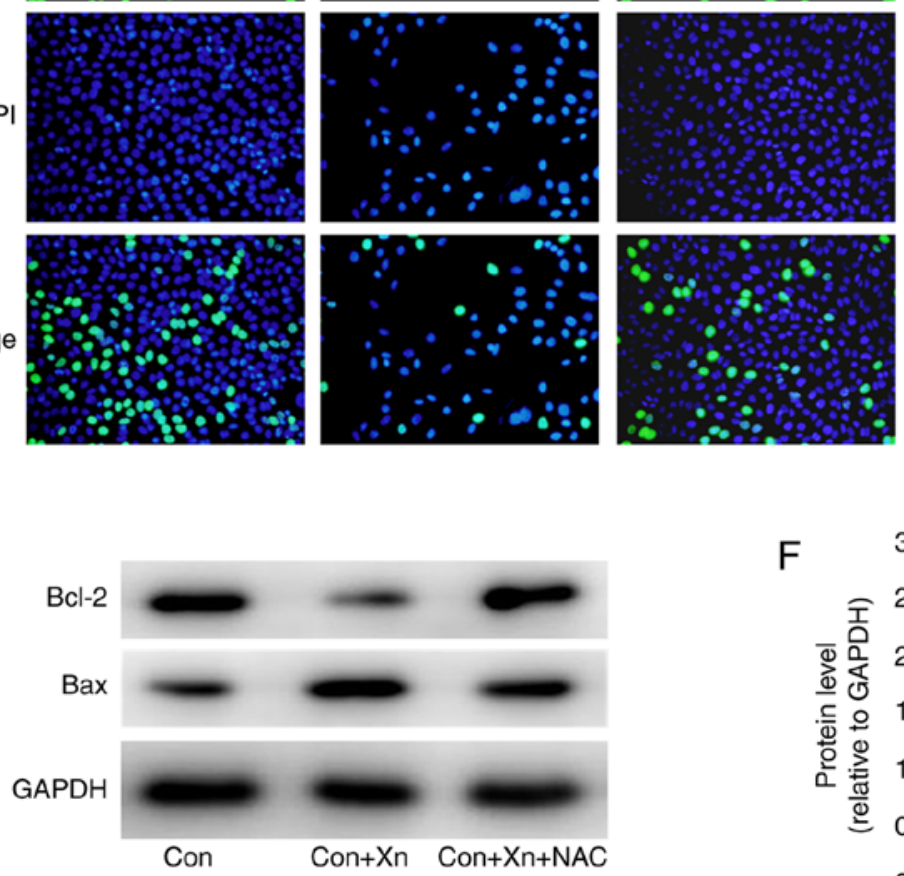

B
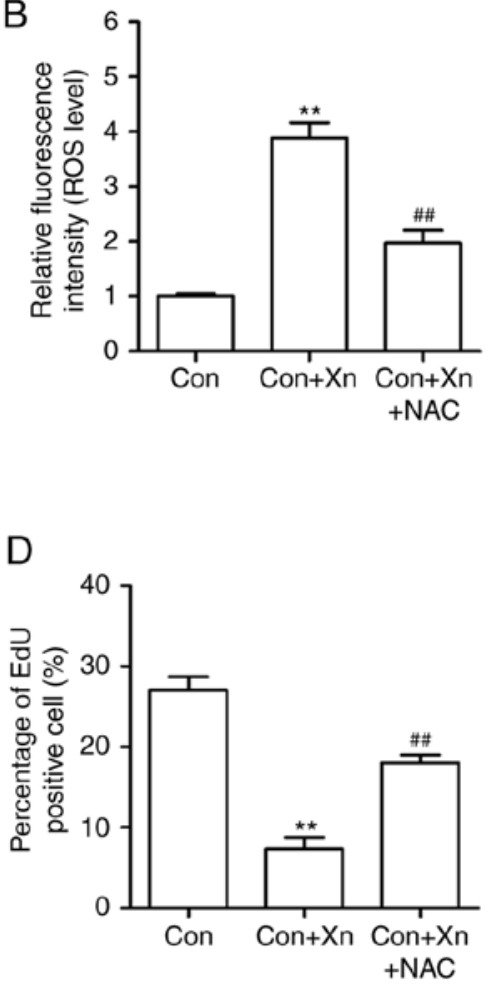

G

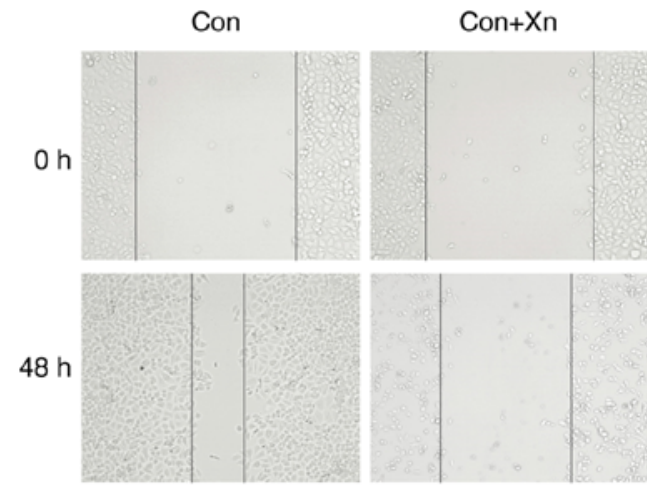

$\mathrm{Con}+\mathrm{Xn+NAC}$

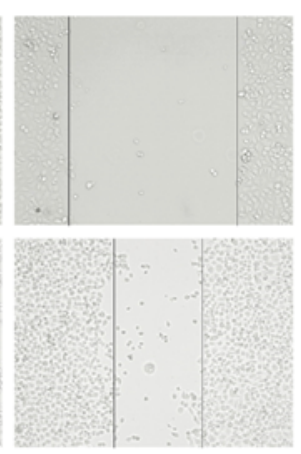

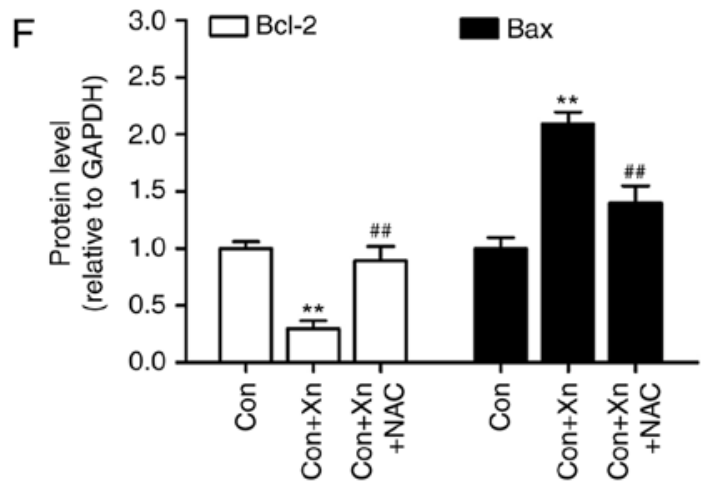

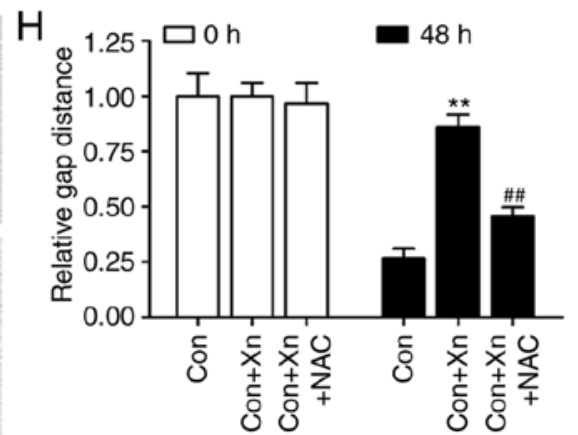

Figure 7. Effect of the reactive oxygen species (ROS) inhibitor N-acetylcysteine (NAC) on the anticancer activity of xanthohumol (Xn) against GC. Cells were pretreated with the ROS inhibitor NAC $(5 \mathrm{mM})$ for $1 \mathrm{~h}$, and then treated with Xn $(20 \mu \mathrm{M})$ for $3 \mathrm{~h}$, followed by measurement of ROS level. (A and B) Representative fluorescence images were captured, and red fluorescence intensity reflected the ROS level. Cells were pretreated with NAC (5 mM) for $1 \mathrm{~h}$, and then treated with $\mathrm{Xn}(20 \mu \mathrm{M})$ for $24 \mathrm{~h}$. (C) The EdU incorporation assay was used to assess cell proliferation ability; representative images are shown. (D) Percentage of EdU-positive cells. (E and F) The expression of apoptosis-related proteins, including the pro-apoptotic protein Bax and the anti-apoptotic protein Bcl-2, was measured through western blotting. ( $\mathrm{G}$ and $\mathrm{H}$ ) The relative wound width was measured following treatment with $\mathrm{Xn}$ for 0 and $48 \mathrm{~h}$. Con, control. Data are expressed as mean \pm standard error of the mean. $\mathrm{n}=3$. $^{* *} \mathrm{P}<0.01$ vs. control $(0 \mu \mathrm{M} \mathrm{Xn}) ;{ }^{\# \#} \mathrm{P}<0.01$ vs. Xn $(20 \mu \mathrm{M} \mathrm{Xn})$. 
A
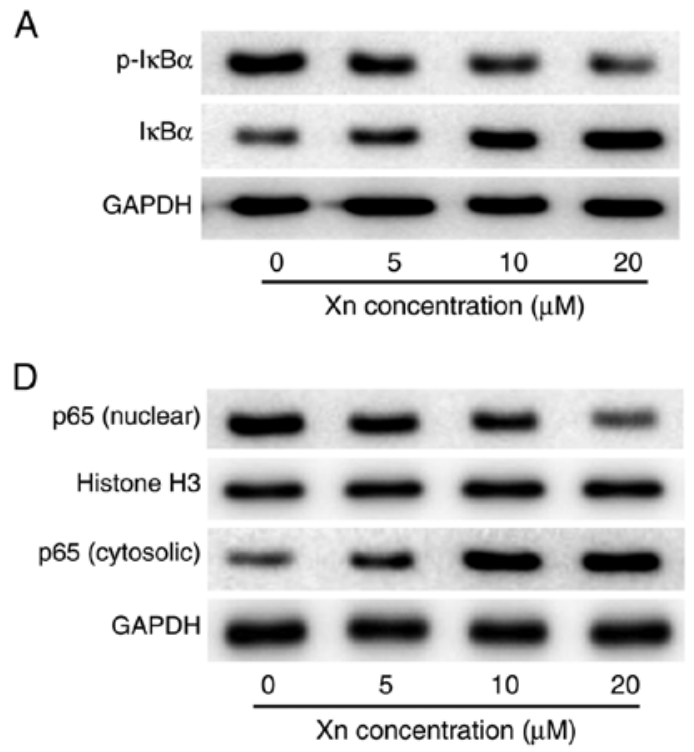
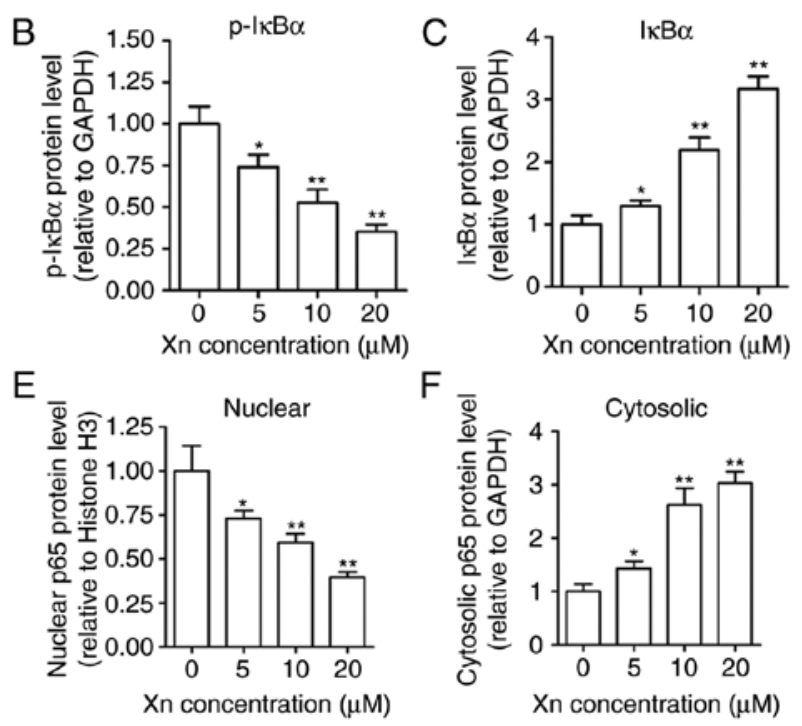

Figure 8. Effect of xanthohumol (Xn) on the nuclear factor (NF)- $\kappa \mathrm{B}$ signaling pathway in AGS cells. Cells were treated with different concentrations of Xn $(0-20 \mu \mathrm{M})$ for $24 \mathrm{~h}$, then harvested and lysed to measure NF- $\kappa \mathrm{B}$ signaling proteins through western blotting. (A-C) Effects of Xn on I $\mathrm{B} \alpha$ and $\mathrm{p}-\mathrm{I} \kappa \mathrm{B} \alpha$ expression. (D-F) Effect of Xn on nuclear and cytosolic p65 expression. Histone H3 served as the nuclear loading control and GAPDH served as the cytosolic loading control. Data are expressed as mean \pm standard error of the mean. $\mathrm{n}=3$. ${ }^{*} \mathrm{P}<0.05,{ }^{* *} \mathrm{P}<0.01$ vs. control $(0 \mu \mathrm{M} \mathrm{Xn})$.

A

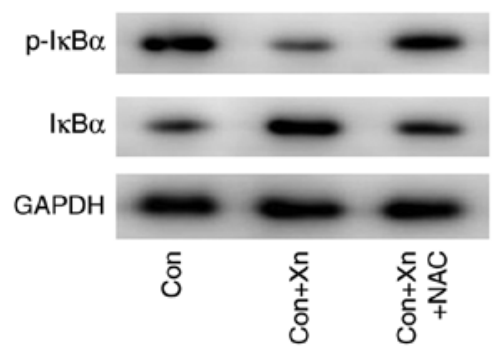

D

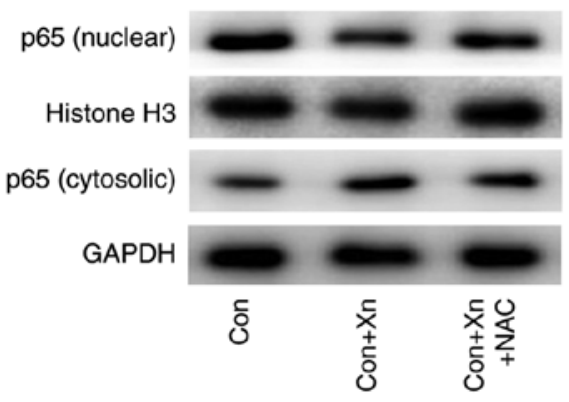

B

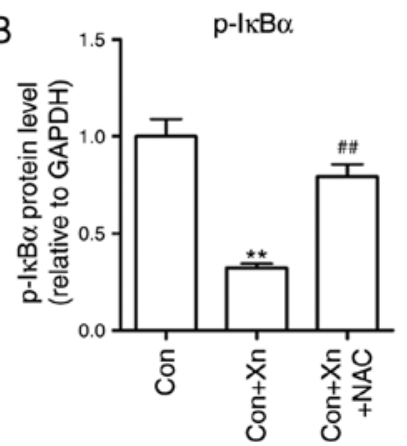

E

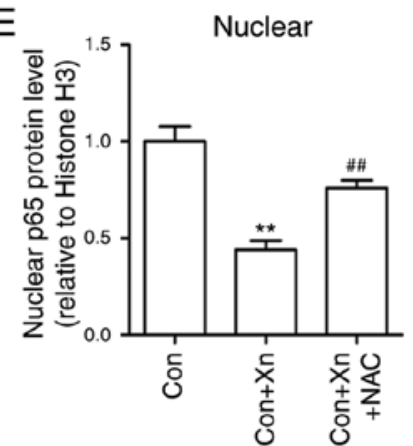

C

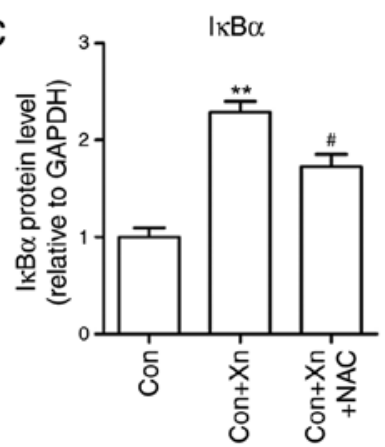

$\mathrm{F}$

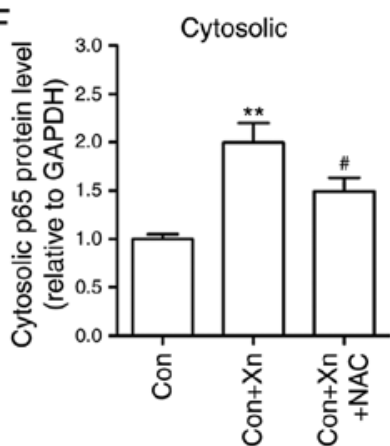

Figure 9. Effect of the reactive oxygen species (ROS) inhibitor N-acetylcysteine (NAC) on the nuclear factor (NF)-кB signaling pathway in xanthohumol (Xn)-treated AGS cells. Cells were pre-treated with the ROS inhibitor NAC $(5 \mathrm{mM})$ for $1 \mathrm{~h}$, and then treated with Xn (20 $\mu \mathrm{M})$ for $24 \mathrm{~h}$; they were then

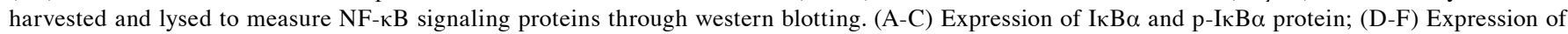
nuclear and cytosolic p65 protein. Histone $\mathrm{H} 3$ served as the nuclear loading control, GAPDH served as the cytosolic loading control. Data are expressed as mean \pm standard error of the mean. $\mathrm{n}=3 .{ }^{* *} \mathrm{P}<0.01$ vs. control $(0 \mu \mathrm{M} \mathrm{Xn}) ;{ }^{\#} \mathrm{P}<0.05,{ }^{\# \#} \mathrm{P}<0.01$ vs. $\mathrm{Xn}(20 \mu \mathrm{M} \mathrm{Xn})$.

\section{Discussion}

Hops, a principle raw material of beer, is widely used in the brewing industry worldwide. Hops acts as a preservative and gives beer its unique aroma and flavor $(17,18)$. In addition, hops has long been used as a medicinal plant, as it is rich in a variety of phenolic compounds (19). Dried hops contains
4-14\% polyphenols, mainly phenolic acids, prenylated chalcones, flavonoids, catechins and proanthocyanidins (20). As the most abundant prenylated flavonoid, Xn exhibits extensive biological activities.

The structure of Xn was first identified by Verzele et al in 1957 (21). However, the beneficial pharmacological properties of Xn, including antioxidant, anti-inflammatory, antibacterial, 
antiviral, antifungal and antiplasmodial activities, were not fully elucidated until the 1990s (22). Recently, the anticancer activity of $\mathrm{Xn}$ was validated in a variety of cancer cells. However, to the best of our knowledge, the present study is the first to investigate the anticancer activity of Xn in GC. We found that Xn dose-dependently decreased the viability of GC cells, particularly AGS cells, with an $\mathrm{IC}_{50}$ as low as $16.04 \mu \mathrm{M}$. It has been reported that Xn exerts very mild or no toxic effects on normal cells, including human lung fibroblast cells (MRC-5), primary human hepatocytes, oligodendroglia-derived cells (OLN-93) and human skin fibroblasts (23-25). Encouraged by the results of these studies, we further investigated the cytotoxicity of Xn on the normal gastric epithelial cell line GES-1. No cytotoxicity was observed up to a concentration of $10 \mu \mathrm{M}$, with an $\mathrm{IC}_{50}$ of up to $285.26 \mu \mathrm{M}$. Moreover, $\mathrm{Xn}$ exerted no effects on the proliferation and apoptosis of GES-1 cells at concentrations of $0-10 \mu \mathrm{M}$. By contrast, $\mathrm{Xn}$ significantly decreased the viability of GC cells from a concentration of $5 \mu \mathrm{M}$, and all the $\mathrm{IC}_{50}$ values in GC cells were higher compared with that in GES-1 cells. These findings indicate that Xn specifically targets GC cells; therefore, Xn may be a safe and effective treatment for GC.

The decreased cell viability may be attributed to inhibition of proliferation or induction of apoptosis. Xn suppressed the proliferation of AGS cells, as indicated by the decreased number of EdU-positive cells. Moreover, flow cytometric analysis revealed an increased number of apoptotic cells upon Xn treatment. Numerous apoptotic-related proteins are involved in the apoptosis process, particularly the Bcl-2 family members. Xn has been reported to induce apoptosis through regulating the expression of Bcl-2 family proteins in several types of cancer $(8,10)$. Bcl-2 family members may be classified into anti- and pro-apoptotic proteins. Most Bcl-2 family members, including Bcl-2, Bcl-XL, Bcl-w, Mcl-1, Bfl1/A-1 and Bcl-B, have anti-apoptotic properties; however, a subset display pro-apoptotic properties, including Bax, Bak and Bid. Among these Bcl-2 family members, the pro-apoptotic protein Bax has been identified as an inhibitory binding partner of $\mathrm{Bcl}-2$, and their expression is commonly used to predict apoptosis (26). In the present study, downregulated Bcl-2 expression and upregulated Bax expression were observed following Xn treatment; this finding, in combination with the results of flow cytometric analysis, suggest that Xn induces apoptosis of AGS cells. As one of the major causes of cancer-related mortality worldwide, $\mathrm{GC}$ has a poor prognosis. Metastasis accounts for the majority of deaths and the poor prognosis, indicating that the prevention and control of metastasis would contribute to improved GC treatment outcome (27). The metastatic ability of AGS cells under Xn treatment was further determined and it was observed that Xn dose-dependently delayed wound healing, cell migration and invasion, suggesting that metastasis of AGS cells is suppressed by Xn. Taken together, these findings indicated that Xn may be a potential anticancer agent via affecting the proliferation, apoptosis and metastasis of GC cells.

It is well-known that oxidative stress plays a key role in several aspects of cancer development and progression, including cellular proliferation, evasion of apoptosis or anoikis, tissue invasion, metastasis and angiogenesis. Thus, cancer treatment is highly associated with regulation of oxidative stress. Although oxidative stress caused by ROS accumulation promotes tumor growth, it can also increase the sensitivity to treatment (28). Numerous commonly used chemotherapeutic agents and phytochemicals with anticancer activity induce ROS production. For example, the cytotoxicity induced by the chemotherapeutic drugs 5-fluorouracil and oxaliplatin is attributed to increased ROS levels (29). Piperlongumine, a bioactive agent derived from the long pepper plant, potently inhibits the growth of breast tumors and metastases in mice by increasing ROS levels (30). Moreover, $\mathrm{Xn}$ induced ROS overproduction in A549 NSCLC cells and T98G glioblastoma cells, resulting in cancer cell apoptosis $(6,11)$. The present study further demonstrated that Xn promoted intracellular ROS production in AGS cells. The damage that ROS causes to cells depends not only on their intracellular concentration, but also on the equilibrium between the ROS and the endogenous antioxidant species (e.g., SOD) (28). In the present study, the relative SOD activity in AGS cells was decreased following exposure to $\mathrm{Xn}$, resulting in ROS overproduction. Furthermore, reduction of ROS by NAC suppressed the effect of Xn on the proliferation, apoptosis and metastasis of AGS cells. These results indicate that ROS mediate the anticancer activity of Xn against GC.

At sublethal levels, ROS have been shown to activate the pro-inflammatory transcription factor, NF- $\mathrm{KB}$, which in turn controls the expression of signaling molecules associated with cancer cell survival. However, high ROS levels reduce NF- $\mathrm{BB}$ activity, resulting in apoptosis of cancer cells (16). Melatonin suppresses thyroid cancer growth and overcomes radioresistance via inhibition of p65 phosphorylation and induction of ROS (31). The induction of ROS overproduction mentioned above prompted us to further explore the effect of $\mathrm{Xn}$ on $\mathrm{NF}-\kappa \mathrm{B}$ signaling in AGS cells. The results demonstrated that $\mathrm{Xn}$ inhibited NF- $\kappa \mathrm{B}$ activity via suppressing I $\mathrm{B} \alpha$ degradation and p65 nuclear translocation. However, the inhibitory effect of Xn on NF- $\mathrm{KB}$ signaling may be reversed by ROS reduction, suggesting that ROS mediates the anticancer activity of Xn against GC via the NF- $\mathrm{KB}$ signaling pathway.

In conclusion, the present study demonstrated that Xn significantly decreases the viability of GC cells, but not that of normal gastric epithelial cells. Xn was shown to inhibit the proliferation, induce apoptosis and suppress metastasis of AGS cells. The underlying mechanism appears to involve ROS overproduction and subsequent inhibition of NF- $\mathrm{kB}$ activity. These results may provide a scientific basis supporting further use of $\mathrm{Xn}$ in the treatment of GC.

\section{Acknowledgements}

Not applicable.

\section{Funding}

The present study was supported by grants from the National Natural Scientific Foundation of China (nos. 81703518, 81703592 and 81573718), the Hunan Provincial Natural Scientific Foundation (no. 2018JJ3571), the Scientific Research Project of Hunan Provincial Health and Family Planning Commission (no. B20180253) and the Open-End Fund for the Valuable and Precision Instruments of Central South University (no. CSUZC201837). 


\section{Availability of data and materials}

The datasets generated during the present study are available from the corresponding author on reasonable request.

\section{Authors' contributions}

WL, DX and BZ conceived and designed the experiments. SW and TS performed the experiments. JD analyzed the data. WL and SW wrote the manuscript. All authors read and approved the final manuscript.

\section{Ethics approval and consent to participate}

Not applicable.

\section{Patient consent for publication}

Not applicable.

\section{Competing interests}

The authors declare that they have no competing interests to disclose.

\section{References}

1. Ajani JA, Bentrem DJ, Besh S, D'Amico TA, Das P, Denlinger C, Fakih MG, Fuchs CS, Gerdes H, Glasgow RE, et al: Gastric cancer, version 2.2013: Featured updates to the NCCN Guidelines. J Natl Compr Cancer Netw 11: 531-546, 2013.

2. Gong J, Cao J, Liu G and Huo JR: Function and mechanism of F-box proteins in gastric cancer (Review). Int J Oncol 47: 43-50, 2015.

3. Singh S, Sharma B, Kanwar SS and Kumar A: Lead phytochemicals for anticancer drug development. Front Plant Sci 7 $1667,2016$.

4. Hosseini A and Ghorbani A: Cancer therapy with phytochemicals: Evidence from clinical studies. Avicenna J Phytomed 5: 84-97, 2015.

5. Chen QH, Fu ML, Chen MM, Liu J, Liu XJ, He GQ and Pu SC: Preparative isolation and purification of xanthohumol from hops (Humulus lupulus L.) by high-speed counter-current chromatography. Food Chem 132: 619-623, 2012.

6. Zhang B, Chu W, Wei P, Liu Y and Wei T: Xanthohumol induces generation of reactive oxygen species and triggers apoptosis through inhibition of mitochondrial electron transfer chain complex I. Free Radic Biol Med 89: 486-497, 2015.

7. Kunnimalaiyaan S, Sokolowski KM, Balamurugan M, Gamblin TC and Kunnimalaiyaan M: Xanthohumol inhibits Notch signaling and induces apoptosis in hepatocellular carcinoma. PLoS One 10: e0127464, 2015.

8. Yoo YB, Park KS, Kim JB, Kang HJ, Yang JH, Lee EK and Kim HY: Xanthohumol inhibits cellular proliferation in a breast cancer cell line (MDA-MB231) through an intrinsic mitochondrial-dependent pathway. Indian J Cancer 51: 518-523, 2014

9. Benelli R, Venè R, Ciarlo $M$, Carlone S, Barbieri $O$ and Ferrari N: The AKT/NF- $\mathrm{B}$ inhibitor xanthohumol is a potent anti-lymphocytic leukemia drug overcoming chemoresistance and cell infiltration. Biochem Pharmacol 83: 1634-1642, 2012.

10. Deeb D, Gao X, Jiang H, Arbab AS, Dulchavsky SA and Gautam SC: Growth inhibitory and apoptosis-inducing effects of xanthohumol, a prenylated chalone present in hops, in human prostate cancer cells. Anticancer Res 30: 3333-3339, 2010.

11. Festa M, Capasso A, D'Acunto CW, Masullo M, Rossi AG, Pizza $\mathrm{C}$ and Piacente S: Xanthohumol induces apoptosis in human malignant glioblastoma cells by increasing reactive oxygen species and activating MAPK pathways. J Nat Prod 74 $2505-2513,2011$
12. Li Y, Fan S, Koo J, Yue P, Chen ZG, Owonikoko TK, Ramalingam SS, Khuri FR and Sun SY: Elevated expression of eukaryotic translation initiation factor $4 \mathrm{E}$ is associated with proliferation, invasion and acquired resistance to erlotinib in lung cancer. Cancer Biol Ther 13: 272-280, 2012.

13. Chen FZ, Mo XM, Wang QP, Li J and Zhang L: Effects of rosiglitazone on the growth and lymphangiogenesis of human gastric cancer transplanted in nude mice. Oncol Rep 30: 2705-2712, 2013.

14. Zuo ZK, Gong Y, Chen XH, Ye F, Yin ZM, Gong QN and Huang JS: TGF $\beta 1$-induced lncRNA UCA1 upregulation promotes gastric cancer invasion and migration. DNA Cell Biol 36: 159-167, 2017.

15. Tong XP, Ma YX, Quan DN, Zhang L, Yan M and Fan XR: Rosemary extracts upregulate Nrf2, Sestrin2, and MRP2 protein level in human hepatoma HepG2 cells. Evid Based Complement Alternat Med 2017: 7359806, 2017.

16. Fouani L, Kovacevic Z and Richardson DR: Targeting oncogenic nuclear factor kappa B signaling with redox-active agents for cancer treatment. Antioxid Redox Signal, 2018.

17. McAdam EL, Freeman JS, Whittock SP, Buck EJ, Jakse J, Cerenak A, Javornik B, Kilian A, Wang CH, Andersen D, et al: Quantitative trait loci in hop (Humulus lupulus L.) reveal complex genetic architecture underlying variation in sex, yield and cone chemistry. BMC Genom 14: 360, 2013.

18. Dostálek P, Karabín M and Jelínek L: Hop phytochemicals and their potential role in metabolic syndrome prevention and therapy. Molecules 22: E1761, 2017.

19. Zanoli P and Zavatti M: Pharmacognostic and pharmacological profile of Humulus lupulus L. J Ethnopharmacol 116: 383-396, 2008.

20. Nikolic D and van Breemen RB: Analytical methods for quantitation of prenylated flavonoids from hops. Curr Anal Chem 9: 71-85, 2013.

21. Verzele M, Stockx J, Fontijn F and Anteunis M: Xanthohumol, a new natural chalkone. J Agric Food Chem 66: 452-475, 1957.

22. Liu M, Hansen PE, Wang G, Qiu L, Dong J, Yin H, Qian Z, Yang $M$ and Miao J: Pharmacological profile of xanthohumol, a prenylated flavonoid from hops (Humulus lupulus). Molecules 20: 754-779, 2015.

23. Dorn C, Weiss TS, Heilmann J and Hellerbrand C: Xanthohumol, a prenylated chalcone derived from hops, inhibits proliferation, migration and interleukin-8 expression of hepatocellular carcinoma cells. Int J Oncol 36: 435-441, 2010.

24. Sławińska-Brych A, Król SK, Dmoszyńska-Graniczka M, Zdzisińska B, Stepulak A and Gagoś M: Xanthohumol inhibits cell cycle progression and proliferation of larynx cancer cells in vitro. Chem Biol Interact 240: 110-118, 2015.

25. Yong WK,Ho YF and Malek SN: Xanthohumol induces apoptosis and S phase cell cycle arrest in A549 non-small cell lung cancer cells. Pharmacogn Mag 11 (Suppl 2): S275-S283, 2015.

26. Hardwick JM and Soane L: Multiple functions of BCL-2 family proteins. Cold Spring Harb Perspect Biol 5: a008722, 2013.

27. Obermannová R and Lordick F: Management of metastatic gastric cancer. Hematol Oncol Clin North Am 31: 469-483, 2017.

28. Sosa V, Moliné T, Somoza R, Paciucci R, Kondoh H and ME LL: Oxidative stress and cancer: An overview. Ageing Res Rev 12: 376-390, 2013.

29. Afzal S, Jensen SA, Sørensen JB, Henriksen T, Weimann A and Poulsen HE: Oxidative damage to guanine nucleosides following combination chemotherapy with 5-fluorouracil and oxaliplatin. Cancer Chemother Pharmacol 69: 301-307, 2012.

30. Raj L, Ide T, Gurkar AU, Foley M, Schenone M, Li X, Tolliday NJ, Golub TR, Carr SA, Shamji AF, et al: Selective killing of cancer cells by a small molecule targeting the stress response to ROS. Nature 475: 231-234, 2011.

31. Zou ZW, Liu T, Li Y, Chen P, Peng X, Ma C, Zhang WJ and Li PD: Melatonin suppresses thyroid cancer growth and overcomes radioresistance via inhibition of $\mathrm{p} 65$ phosphorylation and induction of ROS. Redox Biol 16: 226-236, 2018.

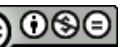

This work is licensed under a Creative Commons Attribution-NonCommercial-NoDerivatives 4.0 International (CC BY-NC-ND 4.0) License. 